\title{
Reseña de Lastra, María Soledad, Volver del exilio. Historia comparada de las políticas de recepción en las posdictaduras de la Argentina y Uruguay (1983-1989), Buenos Aires, Universidad Nacional de La Plata / Universidad Nacional de Misiones / Universidad Nacional de General Sarmiento, 2016, 300 págs.
}

\author{
MARÍA VIRGINIA PISARELLO (UNL-UADER) \\ Universidad Nacional del Litoral / Universidad Autónoma de Entre Ríos \\ mvpisarello@gmail.com
}

El presente libro es una referencia obligada para todo aquel que se adentre en el campo de estudios sobre los exilios políticos de la última dictadura ć́vico-militar. Si bien es cierto que se enfoca concretamente sobre las políticas de recepción de exiliados en Argentina y Uruguay durante las posdictaduras, tiene la virtud de presentar un amplio recorrido que nos acerca al pasado reciente de ambos países desde una perspectiva novedosa. Es una obra de síntesis, basada en la tesis doctoral de María Soledad Lastra, que propone un recorte novedoso basado en la comparación entre los casos argentino y uruguayo.

La autora encuentra semejanzas y disonancias entre ambos casos, ubicando en su especificidad los nudos emblemáticos de las historias recientes de estos países. Así, la figura de la desaparición forzada aparece como un hecho clave en el caso argentino, mientras que las continuidades políticas del Uruguay no encuentran su homólogo al otro lado del Río de la Plata.

Se trata de un trabajo riguroso, en el cual Lastra recupera un profuso corpus documental, dentro del cual es de destacar la consulta de acervos documentales que hasta el momento no habían sido trabajados. La originalidad de las fuentes, y el modo de interpelarlas hacen de la obra una interesante hoja de ruta que abre nuevos horizontes a la vez que instala una serie de mojones para pensar los retornos del exilio.

Lastra se pregunta “¿quiénes regresaron?” y “¿cómo lo hicieron?”, y por esta vía nos permite repensar las sociedades posdictatoriales (1983-1989) que "recibieron" a los exiliados del período inmediatamente precedente. En la primera parte del libro se concentra en las postrimerías de la dictadura, cuando el retorno no parecía posible, pese a que ya se avizoraba una salida democrática en la Argentina y en Uruguay. Reconstruye los perfiles generales de los exilios de ambos países e indaga sobre el papel que tuvieron los partidos políticos y las organizaciones de izquierda armada en el tema. La indagación sobre el retorno colectivo da lugar al análisis de las sociedades argentina y uruguaya, que en menos de una década operaron como sociedades de expulsión y de acogida. Y en este marco atiende al rol de las organizaciones de derechos humanos y los partidos políticos.

Estos actores institucionales y no institucionales cobran protagonismo en la segunda parte del libro, donde analiza los esfuerzos de coordinación y planeamiento de distintas asociaciones de la sociedad civil que abogaron por os mentados retornos. Estudia las raíces que hicieron posible la creación de esas entidades, y recorre las dinámicas que se construyeron entre las organizaciones sociales de Buenos Aires y Montevideo, especialmente entre 1984 y 1986. Al respecto, Lastra subraya los vínculos institucionales que se tejieron entre ambas orillas y revela así la red de transferencia de conocimientos que funcionó en esos años. Asimismo, se detiene en el trabajo de las organizaciones argentinas y uruguayas a través del análisis de la recepción y de los programas de asistencia. 
Por esta vía se concentra en los debates que se suscitaron en torno a los supuestos "privilegios" de los retornados del exilio en relación con otros sectores de afectados por la represión. Aborda una serie de tópicos que siguen siendo sensibles dentro de la agenda pública argentina y uruguaya, entre los que se advierten los escalafones del sufrimiento y las paternidades de la derrota.

En la tercera y última parte, la autora estudia las representaciones, respuestas y políticas específicas que se desarrollaron desde los estados conosureños frente a los retornados. La autora afirma que la pregunta sobre el Estado en la Argentina y en Uruguay "es fundamental para entender cómo fue la recepción de los exiliados a su vuelta". Por esta senda profundiza luego sobre los problemas legales y judiciales que incidieron, en el caso argentino, en la libertad de retornar, aunque no fue así en el caso uruguayo. Particularmente se detiene en el trabajo realizado por la Comisión Nacional para el Retorno de los Argentinos en el Exterior, en Argentina y, la Comisión Nacional de Repatriación, en Uruguay. Sus formas de trabajo, propósitos y dinámicas revelan el sustrato sobre el cual se asentaron las posdictaduras a la vez que dejan entrever las tensiones estructurales que anidaban en su seno.

Por consiguiente, Volver del exilio recorre una serie de temas que siguen siendo muy caros para las memorias sociales que circulan sobre la dictadura y la posdictadura en la región. La pregunta por los exiliados no deja de ser una invitación a bucear en océano de las sociedades de expulsión y de retorno, donde la cuestión de los "privilegios" de los exiliados sigue vigente. De este modo, Lastra discute los metarrelatos nacionales de Argentina y de Uruguay, que presentan a ambos países como "sociedades de acogida" conforme a su pasado receptor de inmigración europea entre finales del siglo XIX e inicios del siglo XX.

Lastra recorre una serie de coyunturas clave que cimentaron las construcciones de la memoria social durante el período 1983-1989. Al hacerlo deslinda una serie de capas de memoria que aún hoy dotan de sentido los relatos del exilio que muy tardíamente ingresaron en la esfera pública argentina. Rehabilita así las voces de los sobrevivientes y desnuda los mecanismos puestos en marcha por los Estados postdictatoriales para "recibir" a los exiliados y consecuentemente borrar las identidades construidas en el fragor de la lucha.

La agenda de investigación que recorre Lastra amplía la apuesta de los estudios tradicionales sobre el exilio político. Avanza desde una perspectiva académica sobre ciertas cuestiones que siguen siendo punzantes en la agenda social e instala una serie de debates que desde una perspectiva comparada se enriquecen y retroalimentan.

$V$ olver del exilio es un libro clave para adentrarse en el campo de estudios sobre los exilios políticos de la última dictadura cívico-militar, y también para analizar las transiciones democráticas en el Cono Sur. Anclado en las políticas de retorno implementadas en Argentina y Uruguay, proyecta una mirada aguda sobre los conflictos políticos que atravesaron las transiciones democráticas en ambos países. La violencia política de los años precedentes y la llamada "judicialización del pasado" emergen aquí como cuestiones centrales dentro de una trama compleja que anuda presente y pasado del Cono Sur. 